\title{
Biodeterioration of Glass-Based Historical Building Materials: An Overview of the Heritage Literature from the 21st Century
}

\author{
Maria Filomena Macedo ${ }^{1,2, *}$, Márcia Gomes Vilarigues ${ }^{1,2}$ and Mathilda L. Coutinho $^{3}$ \\ 1 Departamento de Conservação e Restauro, Faculdade de Ciências e Tecnologia, Universidade NOVA de Lisboa, \\ Campus Caparica, 2829-516 Caparica, Portugal; mgv@fct.unl.pt \\ 2 VICARTE, Research Unit Vidro e Cerâmica para As Artes, Faculdade de Ciências e Tecnologia, \\ Universidade NOVA de Lisboa, Campus Caparica, 2829-516 Caparica, Portugal \\ 3 Laboratório HERCULES-IFAA, Universidade de Évora, 7000-809 Évora, Portugal; mathildal@gmail.com \\ * Correspondence: mfmd@fct.unl.pt
}

Citation: Macedo, M.F.; Vilarigues, M.G.; Coutinho, M.L.

Biodeterioration of Glass-Based Historical Building Materials: An Overview of the Heritage Literature from the 21st Century. Appl. Sci. 2021, 11, 9552. https://doi.org/10.3390/ app11209552

Academic Editor: Sergio Montelpare

Received: 30 July 2021

Accepted: 9 October 2021

Published: 14 October 2021

Publisher's Note: MDPI stays neutral with regard to jurisdictional claims in published maps and institutional affiliations.

Copyright: (c) 2021 by the authors. Licensee MDPI, Basel, Switzerland. This article is an open access article distributed under the terms and conditions of the Creative Commons Attribution (CC BY) license (https:// creativecommons.org/licenses/by/ $4.0 /)$.

\begin{abstract}
The main goal of this work was to review the 21st century literature (2000 to 2021) regarding the biological colonisation and biodeterioration of glass-based historical building materials, particularly stained glass and glazed tiles. One of the main objectives of this work was to list and systematize the glass-colonising microorganisms identified on stained glass and glazed tiles. Biodiversity data indicate that fungi and bacteria are the main colonisers of stained-glass windows. Glazed tiles are mainly colonised by microalgae and cyanobacteria. Several studies have identified microorganisms on stained glass, but fewer studies have been published concerning glazed tiles. The analysis of colonised samples is a vital mechanism to understand biodeterioration, particularly for identifying the colonising organisms and deterioration patterns on real samples. However, the complexity of the analysis of materials with high biodiversity makes it very hard to determine which microorganism is responsible for the biodeteriogenic action. The authors compared deterioration patterns described in case studies with laboratory-based colonisation experiments, showing that many deterioration patterns and corrosion products are similar. A working group should develop guidelines or standards for laboratory experiments on fungi, bacteria, cyanobacteria, and algae on stained glass and glazed tiles.
\end{abstract}

Keywords: stained glass; glazed tiles; biodiversity; biodeterioration; cultural heritage; laboratory experiments

\section{Introduction}

Glass-based building materials have a long tradition in the construction and ornamentation of buildings. They have been applied in two forms: glass coatings applied over ceramics, or plate glass. The unique properties of glass, namely its transparency and wide variety of colours, have allowed it to become a vehicle for visual arts, contributing to the complex ornamentation of buildings and thus their valuable cultural heritage [1-5].

Glass is produced by fusing a mixture of raw materials-vitrifiers, fluxes, or network modifiers and stabilisers - each with different functions, to obtain a solid amorphous inorganic material [6]. In silicate glasses, which are the focus of the present work, silica (dioxide of silicon, $\mathrm{SiO}_{2}$ ) is the main vitrifier (or network former) building up the glass network. Fluxes (or network modifiers) are added to the composition to lower the melting temperature of silica. To increase its durability, stabilisers are added to replace the highly mobile alkaline ions (network modifiers) in the glass network. To achieve specific properties, minor elements can be added, such as colorants, bleaches, and opacifiers. In ancient glass production, sand and quartz were the main sources of silica [7]. The other compounds varied through time and location. Therefore, ancient glasses were produced with a wide variety of chemical compositions [7], which influence their durability. 
Stained glass, mosaics, and glazed tiles are an integral part of the structure of a historic building, and were designed to be a part of the architectural ensemble. The removal of these architectural elements from the original location signifies a considerable value loss; consequently, their preservation on site is of the utmost importance [5]. However, their preservation on-site raises concerns regarding their conservation, since glasses are particularly sensitive to environmental degradation, and are also very vulnerable to biodeterioration [8-10]. Microbial colonisation is a major problem of these building materials due to the damaging consequences of biodeterioration [10,11]. For decades, research has focused on the characterisation of biological communities based on the taxonomic identification of colonising organisms [12]. The interactions between the substrate and organisms to unveil deterioration processes and, more recently, the influence of environmental conditions on biological colonisation and biodeterioration are now being analysed due to advances in genomic and analytical techniques. In general, studies focus on the relationship between three main factors-organisms, the material, and the environment [13]. Therefore, the research on biodeterioration has been based on the analysis of the colonised substrate of artworks [14,15], on laboratory experiments [16,17], or combining laboratory experiments with case studies [18]. This work aimed to review the 21st century literature regarding glass-based historical building materials, particularly stained glass and glazed tiles. Although glass has been used in mosaics tesserae, and some studies have mentioned biodeterioration, no consistent literature was found $[2,19]$. Therefore, this type of application was not considered in the present work due to the lack of data. The 21 st century literature was analysed and discussed, focusing on the biodiversity and the biodeterioration mechanisms, and comparing case studies and laboratory experiments.

Another goal of this work was to perform a critical review based on the 21st century literature regarding stained glass and glazed tiles, that can be used to assess cultural heritage biodiversity and biodeterioration. This knowledge is crucial to understand biodeterioration mechanisms, and is also very important for planning laboratorial experiments. The analysis of colonised samples is a vital mechanism to understand biodeterioration, particularly for identifying the colonising organisms and deterioration patterns on real samples. In this work, the objective was to analyse the materials and complexity of colonised samples in order to determine which microorganism was responsible for the biodeteriogenic action. The authors compared the deterioration patterns described in case studies with laboratory-based colonisation experiments, showing that many deterioration patterns and corrosion products are similar. A working group should develop guidelines or standards for laboratory-based experiments on fungi, bacteria, cyanobacteria, and algae on stained glass and glazed tiles.

\section{Materials and Methods}

The peer-reviewed literature concerning stained glass and glazed tiles included in the category of cultural heritage, dating from the 21st century (since 2000 to 2021), was dispersed and sometimes difficult to access. Two databases, WoS and Scopus, were consulted for this review, using the specific terms "stained glass" or "glazed tiles", which were combined with the keywords "biodeterioration", "bioreceptivity", "microorganisms", "microbial", "fungi", "algae" and "bacteria". All three authors undertook distinct data searches. From the total number of obtained results, the final results were manually selected. The total amount of biodiversity data collected from the gathered literature can be seen in the supplementary word document (Tables S1-S3). These data were organized in graphs and tables to allow a better understanding of the subject. The data allowed the study of biological colonisation in cultural heritage buildings, and should provide a basis for future laboratory experiments. 


\section{Results}

\subsection{Type of Silicate Glasses}

Research on the biodeterioration of glass-based historical building materials has focused on several different glass types (Table 1). The classification of silicate glasses depends on the raw materials used for their production, and their final composition $[4,7,20]$. For this work, we based the classification of glass on the main flux: K-rich (main flux is K), mixed alkali (main fluxes are $\mathrm{Na}+\mathrm{K}$ ), Na-rich (main flux is $\mathrm{Na}$ ), and $\mathrm{Pb}$-rich (main flux is $\mathrm{Pb}$ ). Glass types may have additional classifications within subgroups of the categories mentioned above $[4,20]$. Studies on stained glass were the most diverse regarding the type of glass. Three distinct compositional groups of silicate glasses were investigated: K-rich, mixed-alkali, and Na-rich (Table 1).

Table 1. Type of silicate glass used in the glass-based building materials described in the 21th century literature.

\begin{tabular}{|c|c|c|c|c|c|c|}
\hline $\begin{array}{c}\text { Type of } \\
\text { Silicate Glass }\end{array}$ & Vitrifier & Flux & Stabilizer & $\begin{array}{l}\text { Type of } \\
\text { Building } \\
\text { Material }\end{array}$ & $\begin{array}{l}\text { Nr. of } \\
\text { Studies }\end{array}$ & References \\
\hline K-rich & $\mathrm{SiO}_{2}$ & $\mathrm{~K}_{2} \mathrm{O}$ & $\mathrm{CaO}$ & Stained glass & 5 & {$[18,21-23]$} \\
\hline Mixed-alkali & $\mathrm{SiO}_{2}$ & $\mathrm{Na}_{2} \mathrm{O}+\mathrm{K}_{2} \mathrm{O}$ & $\mathrm{CaO}$ & Stained glass & 1 & [18] \\
\hline Na-rich & $\mathrm{SiO}_{2}$ & $\mathrm{Na}_{2} \mathrm{O}$ & $\mathrm{CaO}$ & Stained glass & 3 & {$[24,25]$} \\
\hline Pb-rich & $\mathrm{SiO}_{2}$ & $\mathrm{PbO}$ & $\mathrm{Al}_{2} \mathrm{O}_{3} / \mathrm{CaO}$ & Glazed tiles & 6 & {$[26-31]$} \\
\hline
\end{tabular}

\subsection{Provenance}

The provenance of cultural heritage stain glass and glazed tiles can be seen in Figure 1.

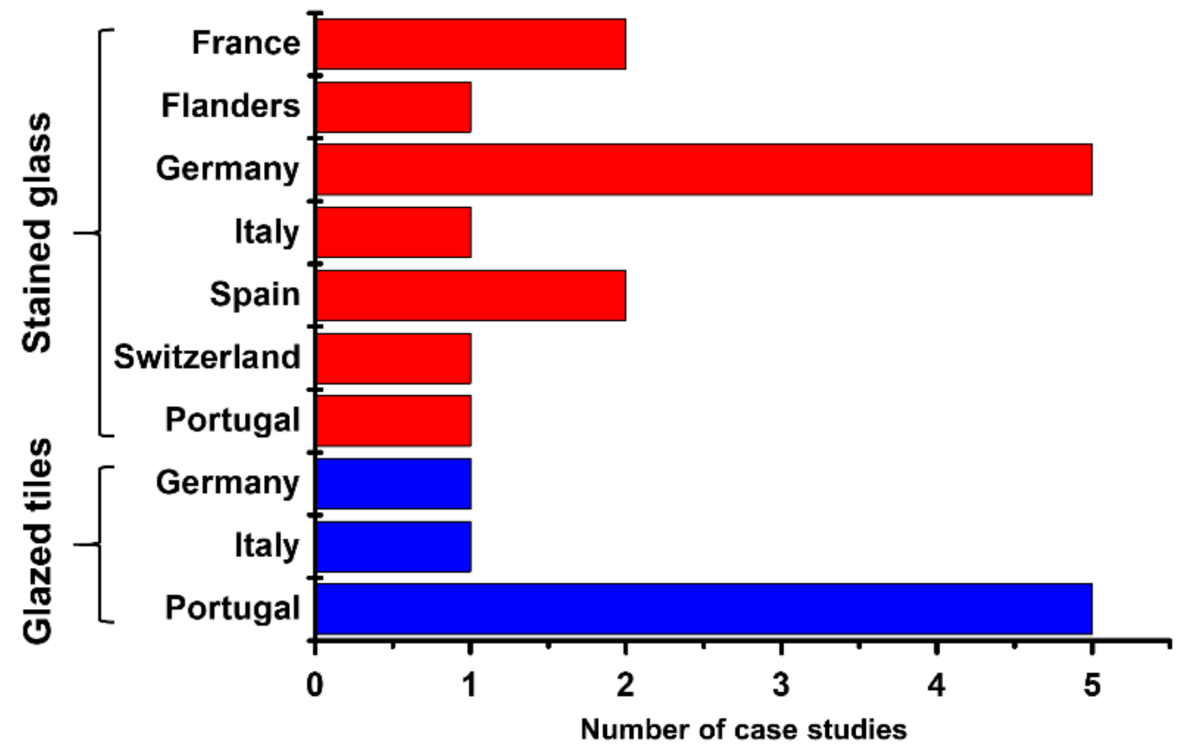

Figure 1. Provenance of the stained glass and glazed tiles with biological colonization from the 21st century literature.

Stained glass studies were made in more locations than glazed tiles. Moreover, most of the stained glass works of art were from Germany, while the glazed tiles are mostly Portuguese. The reason could be the restoration of several cathedrals and churches in Germany, during the 21st century. These glass windows date from the 12th to 20th century, but the majority belong to the 15th century. The provenance is not necessarily related to the place where these works of art were applied. For example, some studies investigated German tiles located in Brazil, and some Portuguese tiles were also studied in Brazil. 


\subsection{Biodiversity}

The strategy of many microorganisms for settling and developing in hostile environments, such as stained glasses and glazed tiles, is through the production of biofilms (i.e., cells embedded in a matrix of extracellular polymeric substances (EPSs)) that can act as a protective layer [32]. The biofilm can limit solute diffusion and restrict the movement of water and nutrients into or out of its embedded microorganisms [10]. Biofilm constituents include EPSs, water, organic acids, lipids, enzymes, DNA, and organophosphates. Biofilms also have dust, pollen, spores, oil, and coal-fired carbonaceous particles from the atmosphere adhered to them or incorporated as part of the biofilm [33-35].

\subsubsection{Fungi}

The various fungi that have been identified on stained glass and glazed tiles in the literature of the 21st century can be seen in Table S1 and Figure 2. A total of 86 fungal specimens have been identified on stained glass and glazed tiles. The majority belong to the Ascomycota division, and a few to the Basidiomycete (Table S1). On stained glass, 24 different genera were identified: Alternaria, Aspergillus, Aureobasidium, Capnobotryella, Chaetomium, Cladosporium, Coniosporum, Didymella, Engyodontium, Fusarium, Geomyces, Hortaea, Kirschsteiniothelia, Leptosphaeria, Myrothecium, Penicillium, Penidiella, Phoma, Rhodotorula, Sistotrema, Stanjemonium, Trichoderma, Ustilago, and Verticillium. The most diverse genera on stained glass were Aspergillus [21,36,37], Cladosporium [18,23], and Penicillium [18] (Figure 2).

A

STAINED GLASS

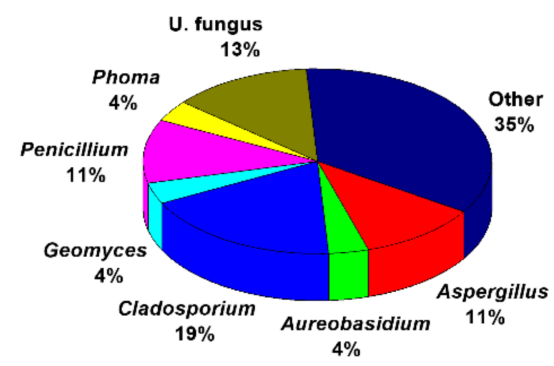

B

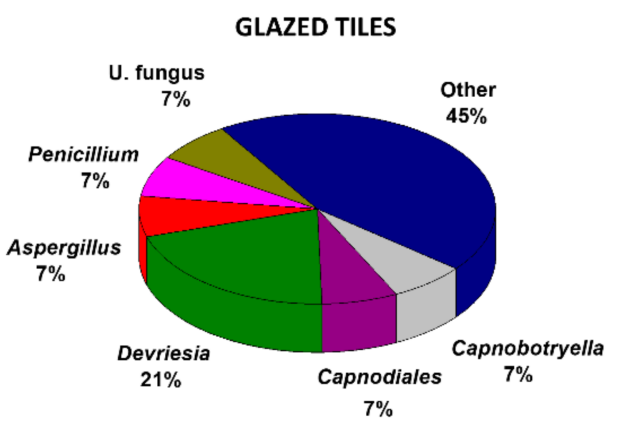

Figure 2. Relative \% of fungal genera reported from the 21 st literature regarding stained glass and glazed tiles. The category "other" refers to a compilation of several genera that occurs less than $3.4 \%$ and "U. fungus" are unidentified fungi. (A) Stained glass. (B) Glazed tiles.

A total of 26 fungal specimens were identified on glazed tiles, which is a much lower number than the fungal biodiversity reported for stained glass (Table S1). These fungi belong to 19 different genera, with the most diverse identified genera on glazed tiles being Devriesia, followed by Aspergillus, Capnobotryella, Capnodiales, and Penicilium (Figure 2). Four Devriesia species, namely Devriesia imbrexigena, Devriesia modesta, Deveriesia neodevriesiaceae, and Devriesia xanthorrheae, were identified on majolica glazed tiles belonging to outdoor wall coverings of two Portuguese monuments [28,38]. In fact, a novel species of this genera, Devriesia imbrexigena, was isolated and described for the first time after being collected from the majolica glazed tiles of the Pena National Palace (Sintra, Portugal) [38] (Table S1).

Figure 3 presents a SEM image of different fungi inoculated over the glass. The glass was partially clean allowing us to see hyphae fingerprints and hyphae over the glass surface. 


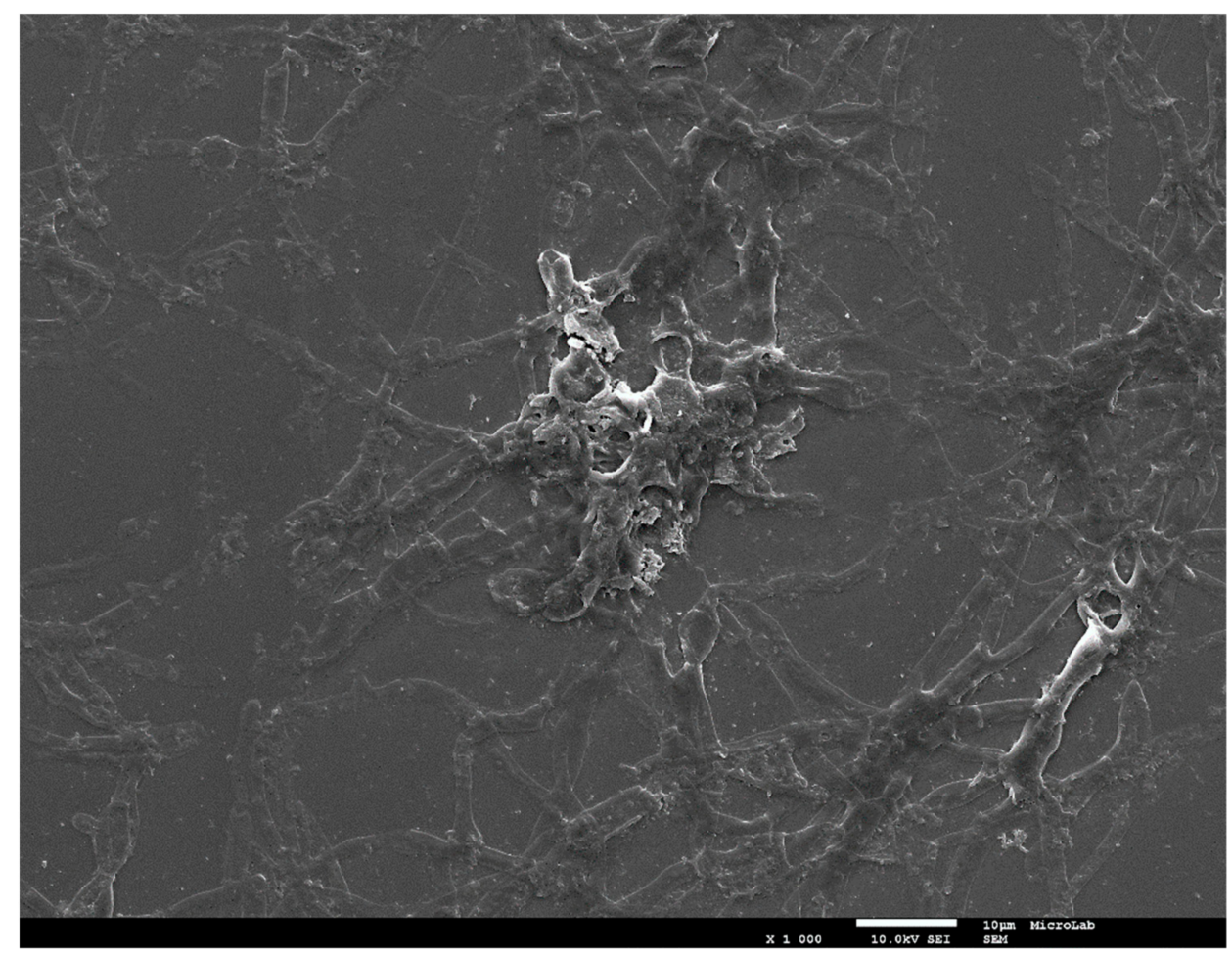

Figure 3. SEM micrography with fungi hyphae on top of glass and hyphae fingerprints (image taken from Ref. [39] with permission of the author).

A small number of fungal genera were simultaneously identified on both types of substrate: Aspergillus, Aureobasidium, Capnobotryella, Fusarium, Penicillum, and Phoma (Table S1). Among the most diverse genera, only Aspergillus and Penicillum occurred on both stained glass and glazed tiles (Figure 2). Aspergillus and Penicillium produce spores which are easily released and dispersed into the air, are omnipresent saprophytes, and dominate in temperate soils where they are frequently identified in both indoor and outdoor environments [40].

\subsubsection{Bacteria}

The bacteria that have been identified on stained glass and glazed tiles from the 21st century literature are summarized in Figure 4 (Table S2). A total of 87 specimens of bacteria have been identified on stained glass and glazed tiles. On stained glass windows, bacteria belonged to five different phyla have been found: Actinobacteria, Bacteroidetes, Firmicutes, Nitrospirae, and Proteobacteria (Figure 4). The most diverse genera were Bacilus [25], Paenibacillus [25], and Kocuria [23]. The microbial populations of the glass biofilms consisted mostly of fungi and bacteria, and fungi were often the dominant group.

A total of 26 bacterial specimens have been identified on glazed tiles, belonging to five different phyla: Actinobacteria, Bacteoidetes, Chloroflexi, Firmicutes, and Proteobacteria. Among these, 13 different genera of bacteria were identified, although few genera had a representative biodiversity (Table S2). Except Methylibium and Microcella, all other genera were represented by only one specimen. This is due to the characterisation of the bacterial communities of glazed tiles being provided from just two case studies [26,29]. Both studies applied molecular biology for the characterisation of the microbial community. The fact that many uncultured species appeared in these results highlights one of the drawbacks of molecular biology (Table S2). Methylibium was the only genera identified simultaneously on stained glass and glazed tiles (Table S2). 
A

STAINED GLASS

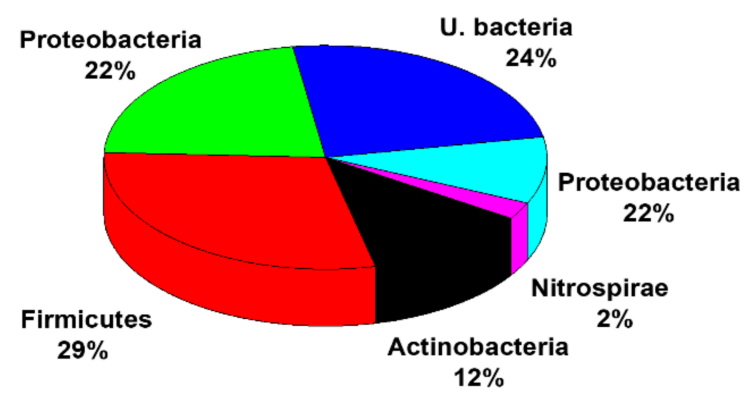

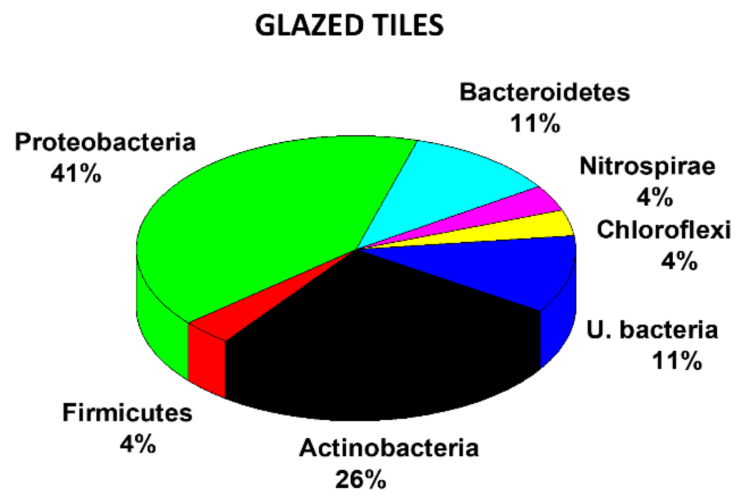

Figure 4. Relative \% of Bacteria Phyla of stained glass and glazed tiles, reported in the literature for the 21st century. The category “U. Bacteria” are unidentified bacteria. (A) Stained glass. (B) Glazed tiles.

\subsubsection{Microalgae, Cyanobacteria and Diatoms}

The phototrophs, including green microalgae, cyanobacteria and diatoms that have been identified in stained glass and glazed tiles literature of the 21st century and were we summarized this knowledge Figure 5 (Table S3). The presence of phototrophs on stained, was limited to 2 cyanobacteria (one Gloeocapsa sp. and one Oscillatoria sp.), both were reported on stained glass in Mausoleum of the Assis Chermont in Brazil (Table S3) [24]. In the same stained glass window a rotifera was also identified. Nevertheless, other authors, not from the 21st century literature refer green biofilms on glass windows [41].

A

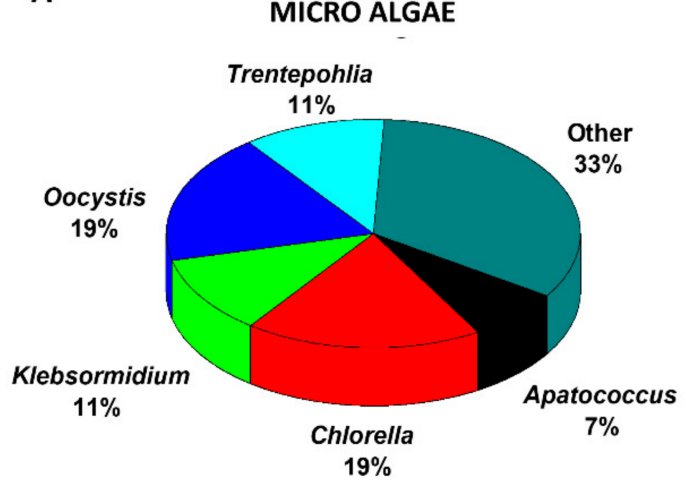

B

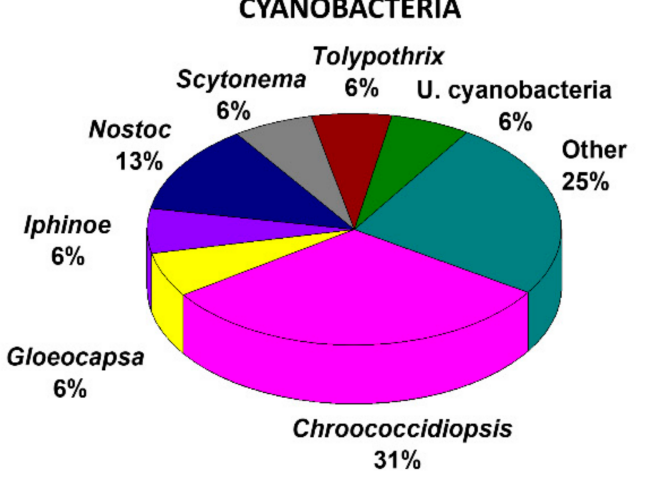

Figure 5. Relative percentage of genera of phototrophic microorganisms reported in the literature for the 21st century on glazed tiles. (A) Micro algae and (B) Cyanobacteria. The category "Other" refers to a compilation of several genera that occurs less than $3.4 \%$ and "U. cyanobacterium" are unidentified cyanobacterium.

On glazed tiles, a total of 27 specimens of green algae (Table S3), belonging to 14 different genera, were identified. The majority of the identified genera belonged to the Chlorophyta phylum, although a few Charophyta were also identified. The genera of green algae in which more than one specimen was reported were Apatococcus, Chlorella, Klebsormidium, Oocystis, and Trentepohlia (Figure 5). All these genera are common colonisers of stone monuments located in the Mediterranean basin [42].

Regarding the bacterial phototrophs, a total of 14 genera of cyanobacteria were identified on glazed tiles. The most diverse cyanobacterial genera were Chroococidiopsis, Gleocapsa, Iphinoe, Nostoc, Scytomena, and Tolypotrix. Except for Iphinoe and Tolypotrix, all the have been found colonising several monuments of the Mediterranean basin [42]. Tolytrix has been identified on several building façades in India [43].

Most of the identified microorganisms were detected by traditional molecular biology methods. However, nowadays, the characterisation of the colonising organisms involves 
understanding the structure and function of the microbial communities, detecting the metabolically active fraction, and identifying the functional diversity. This information can only be obtained by multiproxy approaches combining: (i) cultivation and classical taxonomy [44]; (ii) classical molecular biology techniques, based on Sanger-sequencing and widely applied in the field of cultural heritage [45,46]; and (iii) next generation sequencing (NGS), which is still poorly explored in the field cultural heritage for functional gene analysis to identify metabolic processes related to biodeterioration mechanisms [46]. Several studies have been undertaken to identify the microbial communities colonising stained glass and glazed tiles (e.g., $[18,24,27,29,47])$. In these studies, the identification of microorganisms was by direct observation [24,27]. Some works presented a more detailed characterisation of the stained glass biodeteriogens by using molecular techniques that allowed the identification of bacterial communities [25], or both fungal and bacterial communities [23]. On glazed tiles, some used exclusively molecular techniques [26] and others also combined both culture or direct observation $[28,29]$. However, among studies on stained glass and glazed tiles, no NGS study has yet been conducted (Supplemental Tables: Tables S1-S3).

Lichens have been studied on stained glass [48], but not recently. On both glazed roofing tiles and glazed tiles, lichens have been reported [11]. However, only glazed roofing tiles have been more extensively studied $[49,50]$. Bryophyta has been reported on glazed tiles, although no specific identification was made. This type of organism may not be able to grow on stained glass, since they need a substrate with a high porosity.

The data reported from the 21st century literature indicate that fungi and bacteria dominate the stained glass window colonisers. Glazed tiles can also be colonized by macroalgae and cyanobacteria.

\subsection{Biodeterioration Studies}

The analysis of colonised glass-based historical materials is the first approach to tackle biodeterioration through the identification of biophysical and biochemical alterations that appear on those materials. Many studies have focused on the analysis of deteriorated stained glass windows or glazed tiles with biological colonisation. The microbe-substrate interactions can be investigated through microscopic techniques, such as optical microscopes [21,24], scanning electron microscopes [21,24,28,29], or confocal microscopes [29]. Aesthetical and morphological alterations of the glass surface can be detected through these techniques. The main surface alterations reported on the colonised glasses were iridescence, etching, cracks, and corrosion pits (Table 2). Often, these deterioration forms were observed close to the colonized areas, and were consequently attributed to biodeterioration $[21,23,29]$. Besides these alterations, shifts in the chemical composition of the surface, due to leaching or enrichment of certain elements, are often mentioned. Moreover, the identification of crystals and other deposits on the surface is frequent on colonised glasses or glazes (Table 2). Often, the chemical or mineralogical characterisation of these compounds finds that Ca-rich minerals are the most common compounds (e.g., calcite, oxalates, and syngenite) [21,24] (Table 2). Piñar et al. [23] performed X-ray diffraction and identified several types of compounds on the stained glass windows of two churches located in Spain, specifically sulfates ( $\mathrm{Ca}, \mathrm{K}$, and $\mathrm{Na}$ ), carbonates (Ca), oxides ( $\mathrm{Si}$ and $\mathrm{Mn}$ ), and oxalates (Ca). Mn compounds, identified as bixbyite, were also identified on these medieval stained glass windows [23]. Dark stains rich in Mn were also reported on the stained glass windows from the Les Noes-Pres-Troyes Church (Aube, France) [51]. On glazed tiles, the presence of surface deposits has also been described. The CMSL analysis of the surface of glazed tiles from the Pena National Palace revealed the presence of inorganic deposits close to microorganisms, and a matrix of extracellular polymeric substances (EPSs) [29]. On glazed tiles, microbial colonisation does not always occur on the surface, and some studies have analysed chasmolithic colonisation under the glaze [26,27,30,52]. Only one study identified a green chemical compound, chromium oxide, under the surface, although the authors did not consider it to have a biological origin [30]. In other studies, the identification of precipitation or chemical alteration was not performed (Table 2). Research of the glaze-ceramic 
interface could be a crucial step for understanding whether microorganisms are indeed capable of causing the detachment of the glaze, which is major concern in the preservation of glazed ceramic building materials.

Table 2. Main biodeterioration patterns and alteration products identified on case studies on stained glass and glaze tiles from the 21st century bibliography.

\begin{tabular}{|c|c|c|c|c|c|c|}
\hline Material & $\begin{array}{c}\text { Type of } \\
\text { Silicate Glass }\end{array}$ & Organisms & Location & Deterioration & Alteration Products ${ }^{1}$ & Ref. \\
\hline \multirow[t]{4}{*}{$\begin{array}{l}\text { Stained } \\
\text { glass }\end{array}$} & $\begin{array}{l}\text { K-rich } \\
\text { and Na-rich }\end{array}$ & Bacteria and fungi & Outdoors & $\begin{array}{c}\text { Pitting, } \\
\text { micro-cracks and } \\
\text { some } \\
\text { interconnected } \\
\text { micro-cracks }\end{array}$ & $\begin{array}{c}\text { gypsum }\left(\mathrm{CaSO}_{4} \cdot 2 \mathrm{H}_{2} \mathrm{O}\right) \\
\text { bixbyite }\left(\mathrm{Mn}_{2} \mathrm{O}_{3}\right) \\
\text { syngenite }\left(\mathrm{K}_{2} \mathrm{Ca}\left(\mathrm{SO}_{4}\right)\right. \\
\left.\cdot \mathrm{H}_{2} \mathrm{O}\right) \\
\text { thenardite }\left(\mathrm{a}-\mathrm{Na}_{2} \mathrm{SO}_{4}\right) \\
\text { calcite }\left(\mathrm{CaCO}_{3}\right) \\
\text { quartz }\left(\mathrm{SiO}_{2}\right) \\
\text { weddellite, } \\
\left(\mathrm{CaC}_{2} \mathrm{O}_{4} \cdot 2 \mathrm{H}_{2} \mathrm{O}\right) \\
\text { whewellite } \\
\left(\mathrm{CaC}_{2} \mathrm{O}_{4} \cdot \mathrm{H}_{2} \mathrm{O}\right)\end{array}$ & [23] \\
\hline & K-rich & Bacteria and fungi & Outdoors & $\begin{array}{c}\text { Crusts, } \\
\text { interconnected } \\
\text { craters and pits, } \\
\text { whitish deposits }\end{array}$ & White Ca-rich & [21] \\
\hline & K-rich glass & Bacteria and Fungi & Outdoors & $\begin{array}{l}\text { Dark crusts, pits } \\
\text { and craters, white } \\
\text { deposits }\end{array}$ & $\begin{array}{l}\text { Brown-black Mn-rich } \\
\text { deposits }\end{array}$ & [51] \\
\hline & Na-rich & $\begin{array}{c}\text { Cyanobacteria rotifer, } \\
\text { fungi } \\
\text { and green algae }\end{array}$ & Indoors & $\begin{array}{l}\text { Flaking-off of the } \\
\text { enamels, } \\
\text { interconnected pits, } \\
\text { Iridescence }\end{array}$ & $\begin{array}{l}\text { Soot and calcium } \\
\text { carbonate }\end{array}$ & [24] \\
\hline \multirow[t]{5}{*}{$\begin{array}{l}\text { Glazed } \\
\text { tiles }\end{array}$} & Pb-rich & $\begin{array}{c}\text { Bacteria, } \\
\text { cyanobacteria, algae } \\
\text { and fungi }\end{array}$ & Outdoors & Stains under glaze & & [26] \\
\hline & Pb-rich & $\begin{array}{c}\text { Bacteria, Algae, } \\
\text { cyanobacteria and } \\
\text { fungi }\end{array}$ & Outdoors & Pitting & n.i. inorganic crystals & [29] \\
\hline & Pb-rich & $\begin{array}{l}\text { Algae, cyanobacteria } \\
\text { and fungi }\end{array}$ & Outdoors & Staining and pitting & n.i. crystals & [28] \\
\hline & Pb-rich & Bacteria and Fungi & Indoors & $\begin{array}{l}\text { Underglaze } \\
\text { staining }\end{array}$ & n.i. crystals & [30] \\
\hline & Pb-rich & $\begin{array}{c}\text { Cyanobacteria and } \\
\text { diatomacae }\end{array}$ & Outdoors & $\begin{array}{l}\text { Underglaze } \\
\text { staining }\end{array}$ & - & [27] \\
\hline
\end{tabular}

The attribution of these forms of alteration to biodeterioration is based on the known ability of some microorganisms to excrete metabolic products, such as organic or inorganic acids, that can react with the substrate and solubilise or precipitate compounds $[10,53-56]$. Except for oxalates and Mn-compounds, all the compounds described in Table 2 have previously been identified on glass exposed to outdoor weathering $[9,57,58]$. Minerals such as syngenite $\left(\mathrm{K}_{2} \mathrm{Ca}\left(\mathrm{SO}_{4}\right)_{2} \cdot \mathrm{H}_{2} \mathrm{O}\right)$, gypsum $\left(\mathrm{CaSO}_{4}\right)$, and potassium carbonate $\left(\mathrm{K}_{2} \mathrm{CO}_{3}\right)$ were detected on K-rich silicate glasses exposed to sheltered outdoor conditions [57]. On soda-lime glass, sodium carbonate $\left(\mathrm{Na}_{2} \mathrm{CO}_{3}\right)$ and calcium carbonate $\left(\mathrm{CaCO}_{3}\right)$ crystals have been described as the first signs of deterioration caused by atmospheric corrosion [58]. Analysis of the compounds identified on glass with biological colonisation seem to follow the same trend of abiotic deterioration, in which the cationic part of these salts depends on 
the composition of the glass: $\mathrm{Ca}$ and $\mathrm{K}$-minerals occur in K-rich glass, Na- and K-minerals on Na-K glass samples, and $\mathrm{Na}$ and $\mathrm{Ca}$ minerals on Na-rich glasses [58].

The analysis of colonized samples is vital for understanding biodeterioration, particularly identifying the colonizing organisms and deterioration patterns on real samples. However, the complexity of deterioration resulting from many synergetic and antagonistic factors, such as the environmental factors, makes drawing conclusions based solely on the investigation of colonized samples very difficult. In addition, the analysis of materials with high biodiversity makes it impossible to determine which microorganism was responsible for the biodeteriogenic action.

\subsection{Laboratory Assays with Glass-Based Historical Building Materials}

Laboratory experiments have the advantage of testing the damaging potential of a specific type of organism or group of organisms under controlled conditions. In the gathered literature these experiments use glass models with a chemical composition similar to historical samples. Not only chemical composition has been taken into account for the production of models, but some studies produced samples according to ancient technology. Rodrigues et al. [18] used blown glass since the effect of surface finishing can influence deterioration of glass. Studies regarding stained glass biodeterioration have been performed using K-rich, Mixed alkalis and Na-rich glasses (Table 3), the same glass compositions identified on the case studies (Table 2). K-rich glass was the most studied type of glass. Besides being widely used in stained glass production, it is also the most unstable type of glass so its conservation is a major concern [59].

Table 3. Laboratory experiments performed on glass or glaze models to simulate stained glass and glazed tiles biodeterioration. Time in $w$ means weeks, $m$ means months and $d$ stands for days. The alteration products and biodeterioration patterns are also on this table.

\begin{tabular}{|c|c|c|c|c|c|c|c|}
\hline Material & Organisms & Time & Type of Sil & ate Glass & Alt. Products & Biodeterioration & Ref. \\
\hline \multirow[t]{4}{*}{$\begin{array}{l}\text { Stained } \\
\text { glass }\end{array}$} & Bacteria & $6 \mathrm{w}$. & K-rich & Pristine & $\begin{array}{c}\mathrm{CaCO}_{3} \\
\mathrm{Ca}_{3}\left(\mathrm{PO}_{4}\right)_{2}\end{array}$ & $\begin{array}{c}\text { Micro-cracking } \\
\text { Depletion of } \mathrm{K}, \mathrm{Ca}, \mathrm{P} \text { and } \mathrm{Na} \\
\text { on surface layer } \\
\text { Alteration Mn oxidation-state }\end{array}$ & [51] \\
\hline & Fungi & $6 \mathrm{~m}$. & $\begin{array}{l}\text { Mn-purple } \\
\text { K-rich } \\
\text { Fe-brown } \\
\text { K-rich }\end{array}$ & $\begin{array}{l}\text { Pristine } \\
\text { Corroded } \\
\text { Pristine } \\
\text { Corroded }\end{array}$ & $\begin{array}{c}\mathrm{CaCO}_{3} \\
\mathrm{NaSO}_{4} \cdot \mathrm{H}_{2} \mathrm{O} \\
\mathrm{CaCO}_{3} \\
\mathrm{NaAlSi}_{3} \mathrm{O}_{8} \\
\mathrm{CaSiO}_{3} \\
\text { n.i. } \\
\mathrm{CaCO}_{3} \\
\mathrm{CaCO}_{3} \\
- \\
\mathrm{SiO}_{2} \\
\text { n.i. }\end{array}$ & $\begin{array}{l}\text { Micro-cracking enrichment of } \mathrm{Ca} \\
\text { Biopiting } \\
\text { Hyphae fingerprint crystals } \\
\text { Formation elements depletion } \\
\text { or redeposition }\end{array}$ & [18] \\
\hline & Fungi & $40 \mathrm{~d}$ & $\begin{array}{l}\text { Colourless } \\
\text { K-rich glass }\end{array}$ & & $\begin{array}{c}\mathrm{CaCO}_{3} \text { kalicinite, } \\
\text { whewellite }\end{array}$ & $\begin{array}{l}\text { Glass higher stability present } \\
\text { superficial biofilm and glass } \\
\text { with low chemical stability 3D } \\
\text { growth of the biofilm }\end{array}$ & [22] \\
\hline & Fungi & $5 \mathrm{~m}$. & $\begin{array}{l}\text { Colourless } \\
\text { Na-rich } \\
\text { Colourless } \\
\text { Na-rich } \\
\text { Colourless } \\
\text { Na-rich }\end{array}$ & Pristine & $\begin{array}{l}\text { Ca-rich crystals } \\
\text { Ca-rich crystals }\end{array}$ & $\begin{array}{c}\text { Iridescent stains } \\
\text { crystal formation } \\
\text { slight decrease of the surface } \\
\text { smoothness, } \\
\text { hyphae fingerprints }\end{array}$ & [36] \\
\hline
\end{tabular}


Table 3. Cont

\begin{tabular}{|c|c|c|c|c|c|c|c|}
\hline Material & Organisms & Time & Type of & te Glass & Alt. Products & Biodeterioration & Ref. \\
\hline \multirow[t]{2}{*}{ Glazed tiles } & Phototrophs & $12 \mathrm{~m}$. & Pb-rich & $\begin{array}{l}\text { Pristine } \\
\text { Corroded }\end{array}$ & $\begin{array}{l}\mathrm{CaCO}_{3} \\
\mathrm{CaCO}_{3}\end{array}$ & $\begin{array}{l}\text { Penetration into fissures, } \\
\text { in-prints and surface deposits }\end{array}$ & [16] \\
\hline & Fungus & $12 \mathrm{~m}$. & Pb-rich & Pristine & $\begin{array}{c}\mathrm{CaCO}_{3} \\
\mathrm{CaSO}_{4} \\
\text { Ca-Oxalate } \\
\mathrm{CaCO}_{3} \\
\mathrm{CaSO}_{4} \\
\text { Ca-Oxalate }\end{array}$ & $\begin{array}{c}\text { Mobilization of elements } \\
\text { Formation of Ca-oxalate } \\
\text { crystals }\end{array}$ & [17] \\
\hline
\end{tabular}

Regarding glazes, only lead-alkali glaze opacified with tin was used in the laboratory experiments; no study was performed with transparent lead glazes. White opacified glazes are very common in glazed tiles production, as for many centuries they were used exclusively in Dutch, Portuguese, Spanish, and Italian glazed tile manufacturing. The laboratory-based experiments used the same glaze composition with two different conservation states: pristine and aged. The effect ageing has also been tested for stained glass by using pristine and corroded glass samples [18]. In the field of conservation studies for understanding susceptibility to biodeterioration depending on the degree of ageing, this is very relevant for preserving cultural heritage.

In general, the selection of microorganisms to be used in the biodeterioration laboratory experiments seems to have been based on the biodiversity found on historical materials. Studies have often used microorganisms directly isolated from colonised materials. Fungi identified from stained glass were the most commonly used microorganisms in laboratory studies [18,36,47], although bacteria have also been tested [51]. This may relate to the fact that fungi were the most identified organisms on stained glass with biological colonisation (Table S1). No phototrophic microorganisms were tested, since these have seldom been identified on stained glass windows. As previously mentioned, only two studies have focused on glazed tiles. One used a mixture of phototrophic microorganisms [16], and the other a fungal species isolated directly from historical glazed tiles [17]. Pure culture or multi-species inoculation have advantages and disadvantages. The use of pure cultures allows understanding of whether a specific microorganism is a biodeteriogen. However, multi-species colonies better mimic the real conditions under which biodeterioration take place, since colonisation usually occurs in a community of organisms.

The majority of the studies were performed under high relative humidity conditions, which are optimal for microbial growth and better simulate the conditions under which biofilms develop over historical glasses [16-18,51]. The environmental conditions were usually kept stable during the experiment. Therefore, no daily temperature or relative humidity variations were tested. Stable conditions favour microbial growth, however the simulation of temperature cycles could be relevant for reproducing physical decay. The variation of these parameters could induce volume oscillations of the microorganisms that can induce physical tensions on the substrate. The time span of the experiments varied from a few weeks to one year, making comparisons of the results of different experiments difficult.

After incubation, morphological and compositional changes were investigated through several analytical techniques. On stained glass, the most common biodeterioration forms reported in the laboratory studies were as follows: micro-cracking, enrichment of some elements, pitting, hyphae fingerprints, depletion or enrichment of elements, and deposition of crystalline compounds (Table 3). These were analogous to the deterioration patterns reported in the analysis of colonised historical samples (Table 2). On glazed tiles, the laboratory-based biodeterioration showed that phototrophic microorganisms were able to grow chasmoendolithically on fissures of the glazes, and imprints were visible on the surface [16]. In contrast, fungi did not cause physical or chemical damage to the substrate [17]. 
In general, the selection of microorganism to be used in this biodeterioration laboratory assays seems to be based on the biodiversity found on historical materials. Studies often use microorganisms directly isolated from colonized materials. Fungi identified from stained glass are the most commonly used microorganisms in laboratory studies [18,36,47], although bacteria have also been tested [51]. This may relate to the fact that fungi were the most identified organisms on stained glass with biological colonization (Table S1). No phototrophic microorganisms were tested, since these have seldomly been identified on stained glass windows. Regarding glazed tiles there are only two studies: one using a mixture of phototrophic microorganisms [16] and another a fungal specie isolated from historical glazed tiles [17]. The inoculation of pure culture or multi-species has advantages and disadvantages. The use of pure cultures allows understanding if a specific microorganism is a biodeteriogen. However, multi-species mimic better the real conditions in which biodeterioration occurs, since colonization usually occurs in a community of organisms.

The majority of the studies were performed under high relative humidity conditions, which simulate better the conditions in which biofilms develop over historical glasses [16-18,51]. The environmental conditions are usually kept stable during the experiment. Therefore, no daily temperature or relative humidity variations were tested. Although stable conditions favour the microbial growth, the simulation of temperature cycles could be relevant for simulating physical decay, since the variation of these parameters can induce volume variations of the microorganisms. The time span of the experiments varied from a few weeks to one year so, the comparison between the results of different experiments is difficult.

After the incubation, morphological and compositional changes are investigated through several analytical techniques. On stained glass the most common biodeterioration forms reported in the laboratory studies were: micro-cracking, enrichment of some elements, pitting, hyphae fingerprint, depletion or enrichment of elements and deposition of crystalline compounds (Table 3). Similar to the deterioration patterns reported in the analysis of historical samples (Table 2). On glazed tiles, the laboratory-based biodeterioration showed that phototrophic microorganisms were able to grow chasmoendolithically on fissures of the glazes and imprints were visible on the surface [16]. In contrast, fungi could not cause physical damage on the substrate, but seem to cause deposition of crystals on the surface [17].

In most studies, crystalline compounds were formed on the surface of the glass, implying surface corrosion. The identified compounds were $\mathrm{MnCO}_{3}, \mathrm{CaCO}_{3}, \mathrm{CaSO}_{4}$, $\mathrm{NaSO}_{4} \cdot \mathrm{H}_{2} \mathrm{O}, \mathrm{NaAlSi}_{3} \mathrm{O}_{8}, \mathrm{CaSiO}_{3}, \mathrm{SiO}_{2}, \mathrm{~K}_{2} \mathrm{CO}_{3}$, and $\mathrm{CaC}_{2} \mathrm{O}_{4} \cdot \mathrm{H}_{2} \mathrm{O}$. In some studies, the mineralogical composition of the crystals was not determined; only the chemical composition was considered (Table 3). All these compounds were reported in field studies (Table 3). Ca-rich compounds were the most commonly identified, consistent with the fact that crystalline compounds are often detected on real samples with biological colonisation (Table 3). Only Ca-oxalates could be directly associated with biogenic action [60] due to the reaction of oxalic acid with calcium. Two laboratory-based experiments using fungi detected this compound on stained glass [22] and glazed tiles [17]. Although most of these compounds cannot be directly attributed to microbial activity, some authors have claimed that the precipitation was higher on the colonised samples than the controls. The precipitation of salts over glass is considered harmful, since their presence influences the corrosion rate [57], but these studies seemed to demonstrate the ability of microorganisms to also increase the deterioration rate $[17,18]$.

Regarding colorants, Mn-rich compounds were identified in two studies on the biodeterioration of glass by bacteria [51,61] (Table 2). Rodrigues et al. [18] evaluated the biodeterioration of Fe-brown and Mn-purple K-rich glass, and concluded that the purple glass presented with a high degree of pitting with $\mathrm{K}, \mathrm{Ca}$, and $\mathrm{Na}$ depletions compared to the other studied glass compositions (colourless mixed alkali and Fe-brown K-rich glass). This could indicate a higher susceptibility of these glasses to fungal biodeterioration. Several microorganisms, including bacteria and fungi, have the ability to mobilise Mn [55,62]. 
However, not only Mn can be mobilised by microorganisms; other metals, many used as colouring agents of glass (e.g., Fe, Co, Cu, Cr), can accumulate in microbial biofilms [63,64]. Furthermore, it is also known that certain colorants can influence the corrosion rate of glass. In Vilarigues et al. [65], glasses doped with $\mathrm{Cu}, \mathrm{Mn}$, or Fe and exposed to weathering conditions developed a surface layer richer in the colouring transition-metal ions. The addition of these transition-metal ions, namely $\mathrm{Cu}, \mathrm{Fe}$ and $\mathrm{Mn}$, influenced the beginning of the corrosion process. Such an effect was previously described on medieval stained glasses coloured with metal oxides that had been naturally weathered [66].

Some studies have also addressed bioreceptivity, which is the material's ability to be colonised by living organisms $[13,67]$. On glazed tiles, bioreceptivity was tested and it was found that the colonisation rate of phototrophs was mostly affected by the water permeability. Another study that used the same glaze composition as the previously mentioned study detected no difference in the fungal colonisation rated between pristine and aged tiles. Regarding the bioreceptivity, no study has yet assessed the influence of the properties of the glass, such as composition, ageing, or roughness, on the rate of microbial growth. This is probably due to the difficulty in quantifying the growth of fungi and bacteria, which are the main stained glass colonisers. The only study that has investigated bioreceptivity of glass used a modern glass composition to test the effect of superficial porosity in the growth of phototrophic microorganisms [68]. In comparison with stone, the bioreceptivity of glass and glazed ceramic materials has been little investigated [13]. Nevertheless, several real case studies have mentioned differences in the degree of colonisation depending on the glass composition and colour [24,25]. This is also supported by the fact that some colorants seem to have antimicrobial properties, namely cobalt [69,70] and copper [25]. Therefore, the analysis of the effect of the colorants of glass and glazes on the biodeterioration rate and the inhibition of colonisation is an understudied area that could provide relevant information regarding the susceptibility of glasses to microorganisms depending on their colouring elements.

\section{Discussion}

We were surprised that, until now, the majority of biodiversity and biodeterioration studies have been performed on stained glass works of art coming from Germany. On the other hand, studies on glazed tiles from Portugal are more prevalent in the literature.

Biodiversity data reported from the 21st century literature, indicates that fungi and bacteria are the main colonizer of stained glass windows (Figures 2 and 4). While glazed tiles are also colonized by macroalgae and cyanobacteria. Nevertheless, the authors found that there are several works that identify microorganisms on stained glass and there are less studies published concerning glazed tiles. Still, it is important to study bacteria on glazed tiles since only two studies (Table S2) have been conducted in the 21st century literature. A further research should be performed on green biofilms on stained glass windows, in order to find out if there are phototrophic microorganisms on this glass cultural heritage.

Microbial glass deterioration causes serious damage on glass, not only from the chemical and physical point of view, but also from an aesthetic and iconographic one, since glass loses its transparency. The research of microorganism-glaze-ceramic interface is a crucial step for understanding if microorganisms are indeed capable of causing the detachment of the glaze. Accordingly, biodeterioration should be carefully addressed whenever conservation of historic glass is the issue. Data reported from the 21st century literature regarding bacterial diversity of glazed tiles was determined from only two studies. Both studies applied molecular biology for the characterization of the microbial community [26,29]. The fact that many uncultured species appear in these results and the presence of many unknown species highlights one of the drawbacks of molecular biology (Table S2).

The complexity of biodeterioration studies results from many synergetic and antagonistic factors makes drawing conclusions based solely on the investigation of colonized samples is very difficult. In addition, the analysis of materials with high biodi- 
versity makes it impossible to determine which microorganism was responsible for the biodeteriogenic action.

When laboratory based studies are made the use of pure cultures allows to understand if a specific microorganism is a biodeteriogen. However, multi-species mimic better the real conditions in which biodeterioration occurs, since colonization usually occurs in a community of organisms. Laboratory experiments have the advantage of testing the damaging potential of a specific organism or group of organisms under controlled conditions. However, distinct authors used a different microorganism, time, temperature, light, etc., which make it impossible to compare between distinct studies.

Therefore, a working group should be organized in order to develop guidelines or standards for laboratory-based experiments: for instance, if you have a biofilm with five species you would test the biofim as a whole and each specie separately. Is also important to reproduce the glass or the glaze. It is important to define abiotic factors such as HR, time, temperature, light, the incubation system etc. Microbial glass deterioration causes serious damage to glass, not only from the chemical and physical point of view, but also from an aesthetic and iconographic perspective, since the glass loses its transparency. The research into the microorganism-glaze-ceramic interface is a crucial step for understanding whether microorganisms are indeed capable of causing the detachment of the glaze. Accordingly, biodeterioration should be carefully addressed whenever the conservation of historic glass and glazes tiles is of importance. Conservators must act to achieve the inactivation and removal of the microorganisms in order to halt their progression. The selection of cleaning products and biocides is a complex subject with few optimal solutions, due to the susceptibility of glass to corrosion and the complex biodiversity [28,71]. Additionally, the mechanical removal of biofilms, whether with a simple manual scalpel or through complex laser cleaning, remains in question since microorganisms usually grow close to the glass corrosion layer. In the case of cultural heritage, they are considered part of the original material and also a corrosion-passivating layer; therefore, their removal needs to be carefully evaluated. Protective layers have been investigated, such as antimicrobial [72,73] or anticorrosion $[74,75]$ coatings. However, few or no real case applications have been carried out due to the ethical questions regarding their reversibility, ageing, and interference with aesthetic properties. Further research to understand glass biodeterioration is essential to be able to develop proper conservation guidelines for stained glass and glazed tiles.

The complexity of biodeterioration studies is due to the many synergetic and antagonistic factors that make drawing conclusions based solely on the investigation of colonised samples very difficult. In addition, the analysis of materials with high biodiversity makes it impossible to determine which microorganism was responsible for the biodeteriogenic action. When laboratory-based studies are carried out, the use of pure cultures allows us to understand if a specific microorganism is a biodeteriogen. However, multi-species inoculation better mimics the real conditions under which biodeterioration occurs, since colonisation usually develops in a community of organisms. Laboratory experiments have the advantage of testing the damaging potential of a specific organism or group of organisms under controlled conditions. However, some authors have used different microorganisms, time periods, temperatures, light conditions, etc., which makes it impossible to compare different studies.

Therefore, a working group should be organised in order to develop guidelines or standards for laboratory-based experiments: for instance, outlining procedures for testing biofilms as a whole and each species separately. Is also important to reproduce the glass or the glaze under study. Finally, it is important to define abiotic factors, such as the HR, time period, temperature, light, incubation system, and so forth.

Supplementary Materials: The following are available online at https:/ / www.mdpi.com/article/10 .3390/app11209552/s1, Table S1: Fungi reported on historical stained glass windows and glazed tiles in the literature. Table S2: Bacteria reported on historical stained glass windows and glazed tiles in the literature. Table S3: Prototrophs (cyanobacteria and microalgae), Protista and Rotifera reported on historical stained glass windows and glazed tiles in the literature. 
Author Contributions: Conceptualization, M.F.M., M.G.V., M.L.C.; methodology, M.F.M.; M.G.V. and M.L.C.; investigation M.F.M., M.G.V. and M.L.C.; writing-review and editing, M.F.M., M.G.V., and M.L.C.; funding acquisition, M.G.V. and M.L.C. All authors have read and agreed to the published version of the manuscript.

Funding: This work was supported by National Funds through FCT-Portuguese Foundation for Science and Technology under the projects UID/Multi/04449/2019 HERCULES/UE; and contract CEECIND/00349/2017 (ML. Coutinho) and CityUMacau Chair in Sustainable Heritage. This work was also founded by VICARTE RESEARCH UNIT (UIDB/00729/2020).

Institutional Review Board Statement: Not applicable.

Informed Consent Statement: Not applicable.

Data Availability Statement: Data is contained within the references or in supplementary material.

Conflicts of Interest: The authors declare no conflict of interest.

\section{References}

1. Gnesin, G.G. Glass, Glaze, and Enamel over the Millennia. II. Glazes and Enamels. Powder Met. Met. Ceram. 2016, 54, 750-756. [CrossRef]

2. Verità, M. Technology and deterioration of vitreous mosaic tesserae. Stud. Conserv. 2000, 45, 65-76. [CrossRef]

3. Velo-Gala, A.; Mata, J.A.G. Roman window glass: An approach to its study through iconography. Lvcentvm 2017, 36, 159-176. [CrossRef]

4. Adlington, L.; Freestone, I.; Kunicki-Goldfinger, J.; Ayers, T.; Scott, H.G.; Eavis, A. Regional patterns in medieval European glass composition as a provenancing tool. J. Archaeol. Sci. 2019, 110, 104991. [CrossRef]

5. Carvalho, R.S. To be part of ... architecture, decoration or iconography. Documenting azulejo as integrated heritage. ISPRS Ann. Photogramm. Remote Sens. Spat. Inf. Sci. 2019, 4, 39-46. [CrossRef]

6. Shelby, J.E. Introduction to Glass Science and Technology; The Royal Society of Chemistry: Cambridge, UK, 1997.

7. Rehren, T.; Freestone, I.C. Ancient glass: From kaleidoscope to crystal ball. J. Archaeol. Sci. 2015, 56, 233-241. [CrossRef]

8. Frankel, G.S.; Vienna, J.D.; Lian, J.; Scully, J.R.; Gin, S.; Ryan, J.; Wang, J.; Kim, S.H.; Windl, W.; Du, J. A comparative review of the aqueous corrosion of glasses, crystalline ceramics, and metals. NPJ Mater. Degrad. 2018, 2, 15. [CrossRef]

9. Majérus, O.; Lehuédé, P.; Biron, I.; Alloteau, F.; Narayanasamy, S.; Caurant, D. Glass alteration in atmospheric conditions: Crossing perspectives from cultural heritage, glass industry, and nuclear waste management. NPJ Mater. Degrad. $2020,4,27$. [CrossRef]

10. Weaver, J.L.; DePriest, P.T.; Plymale, A.E.; Pearce, C.I.; Arey, B.; Koestler, R.J. Microbial interactions with silicate glasses. NPJ Mater. Degrad. 2021, 5, 11. [CrossRef]

11. Coutinho, M.L.D.; Miller, A.Z.; Macedo, M.F. Biological colonization and biodeterioration of architectural ceramic materials: An overview. J. Cult. Herit. 2015, 16, 759-777. [CrossRef]

12. Sanmartín, P.; DeAraujo, A.; VasanthaKumar, A. Melding the Old with the New: Trends in Methods Used to Identify, Monitor, and Control Microorganisms on Cultural Heritage Materials. Microb. Ecol. 2018, 76, 64-80. [CrossRef]

13. Sanmartín, P.; Miller, A.; Prieto, B.; Viles, H. Revisiting and reanalysing the concept of bioreceptivity 25 years on. Sci. Total Environ. 2021, 770, 145314. [CrossRef]

14. Messiga, B.; Riccardi, M. Alteration behaviour of glass panes from the medieval Pavia Charterhouse (Italy). J. Cult. Herit. 2006, 7, 334-338. [CrossRef]

15. Szczepanowska, H.; Cavaliere, A. Fungal deterioration of 18th and 19th century documents: A case study of the Tilghman Family Collection, Wye House, Easton. Maryland. Int. Biodeterior. Biodegrad. 2000, 46, 245-249. [CrossRef]

16. Coutinho, M.L.; Miller, A.Z.; Rogerio-Candelera, M.A.; Mirão, J.; Alves, L.C.; Veiga, J.P.; Águas, H.; Pereira, S.; Lyubchyk, A.; Macedo, M.F. An integrated approach for assessing the bioreceptivity of glazed tiles to phototrophic microorganisms. Biofouling 2016, 32, 243-259. [CrossRef] [PubMed]

17. Coutinho, M.; Miller, A.Z.; Phillip, A.; Mirao, J.; Dias, L.; Rogerio-Candelera, M.; Saiz-Jimenez, C.; Martin-Sanchez, P.M.; Cerqueira-Alves, L.; Macedo, M.F. Biodeterioration of majolica glazed tiles by the fungus Devriesia imbrexigena. Constr. Build. Mater. 2019, 212, 49-56. [CrossRef]

18. Rodrigues, A.; Gutierrez-Patricio, S.; Miller, A.Z.; Saiz-Jimenez, C.; Wiley, R.; Nunes, D.; Vilarigues, M.; Macedo, M.F. Fungal biodeterioration of stained-glass windows. Int. Biodeterior. Biodegrad. 2014, 90, 152-160. [CrossRef]

19. Moropoulou, A.; Zacharias, N.; Delegou, E.; Maróti, B.; Kasztovszky, Z. Analytical and technological examination of glass tesserae from Hagia Sophia. Microchem. J. 2016, 125, 170-184. [CrossRef]

20. Tite, M.; Freestone, I.; Mason, R.; Molera, J.; Vendrell-Saz, M.; Wood, N. Lead glazes in antiquity-Methods of Production and reasons for use. Archeometry 1998, 40, 241-260. [CrossRef]

21. Carmona, N.; Laiz, L.; Gonzalez, J.M.; Garcia-Heras, M.; Villegas, M.-A.; Saiz-Jimenez, C. Biodeterioration of historic stained glasses from the Cartuja de Miraflores (Spain). Int. Biodeterior. Biodegrad. 2006, 58, 155-161. [CrossRef] 
22. Müller, E.; Drewello, U.; Drewello, R.; Weißmann, R.; Wuertz, S. In Situ analysis of biofilms on historic window glass using confocal laser scanning microscopy. J. Cult. Herit. 2001, 2, 31-42. [CrossRef]

23. Piñar, G.; Garcia-Valles, M.; Gimeno, D.; Fernandez-Turiel, J.-L.; Ettenauer, J.; Sterflinger, K. Microscopic, chemical, and molecularbiological investigation of the decayed medieval stained window glasses of two Catalonian churches. Int. Biodeterior. Biodegrad. 2013, 84, 388-400. [CrossRef]

24. Pinto, A.M.C.; Sanjad, T.A.; Angélica, R.S.; Da Costa, M.L.; Paiva, R.S.; Palomar, T. 19th century stained-glass windows from Belém do Pará (Brazil): Analytical characterisation and pathology. Boletín Soc. Española Cerámica Vidr. 2018, 57, 133-141. [CrossRef]

25. Marvasi, M.; Vedovato, E.; Balsamo, C.; Macherelli, A.; Dei, L.; Mastromei, G.; Perito, B. Bacterial community analysis on the Mediaeval stained glass window "Natività" in the Florence Cathedral. J. Cult. Herit. 2009, 10, 124-133. [CrossRef]

26. Giacomucci, L.; Bertoncello, R.; Salvadori, O.; Martini, I.; Favaro, M.; Villa, F.; Sorlini, C.; Cappitelli, F. Microbial Deterioration of Artistic Tiles from the Façade of the Grande Albergo Ausonia \& Hungaria (Venice, Italy). Microb. Ecol. 2011, 62, 287-298. [CrossRef] [PubMed]

27. Oliveira, M.M.; Sanjad, T.B.C.; Bastos, C.J.P. Biological degradation of glazed ceramic tiles. In Proceedings of the Historical Constructions; Lourenço, P.B., Roca, P., Eds.; Universidade do Minho: Guimarães, Portugal, 2001; pp. 337-342. Available online: http:/ / www.hms.civil.uminho.pt/events/historica2001/page\%20337-342\%20_17_.pdf (accessed on 8 October 2021).

28. Coutinho, M.L.D.; Miller, A.Z.; Martin-Sanchez, P.M.; Mirao, J.; Gomez-Bolea, A.; Machado-Moreira, B.; Cerqueira-Alves, L.; Jurado, V.; Saiz-Jimenez, C.; Lima, A.; et al. A multiproxy approach to evaluate biocidal treatments on biodeteriorated majolica glazed tiles. Environ. Microbiol. 2016, 18, 4794-4816. [CrossRef] [PubMed]

29. Coutinho, M.L.D.; Miller, A.Z.; Gutierrez-Patricio, S.; Hernandez-Marine, M.; Gómez-Bolea, A.; Rogerio-Candelera, M.A.; Philips, A.; Jurado, V.; Saiz-Jimenez, C.; Macedo, M.F. Microbial communities on deteriorated artistic tiles from Pena National Palace (Sintra, Portugal). Int. Biodeterior. Biodegrad. 2013, 84, 322-332. [CrossRef]

30. Verde, S.C.; Silva, T.; Corregidor, V.; Esteves, L.; Dias, M.I.; Souza-Egipsy, V.; Ascaso, C.; Wierzchos, J.; Santos, L.; Prudêncio, M.I. Microbiological and compositional features of green stains in the glaze of the Portuguese "Great View of Lisbon" tile panel. J. Mater. Sci. 2015, 50, 6656-6667. [CrossRef]

31. Pedi, N.; Conceição, E.; Fernandes, M.J.; Massa, D.; Nogeira, E.; Ribeiro, P.; Arcoverde, J.H.; Lemos, S.; Marsden, A.; Neves, R. Fungos isolados em azulejos do convento de Santo António, Recife, Pernambuco. IX Jornadas de Ensino, Pesquisa e Extensão— \#JEPEX. 2009. Available online: http:/ / www.eventosufrpe.com.br/jepex2009/cd/resumos/r0550-1.pdf (accessed on 8 October 2021).

32. Cuzman, A.O.; Tiano, P.; Ventura, S.; Frediani, P. Biodiversity on Stone Artifacts. In The Importance of Biological Interactions in the Study of Biodiversity; InTech: London, UK, 2011; pp. 367-390.

33. Cecchi, G.; Pantani, L.; Raimondi, V.; Tomaselli, L.; Lamenti, G.; Tiano, P.; Chiari, R. Fluorescence lidar technique for the remote sensing of stone monuments. J. Cult. Herit. 2000, 1, 29-36. [CrossRef]

34. Tourney, J.; Ngwenya, B.T. The role of bacterial extracellular polymeric substances in geomicrobiology. Chem. Geol. 2014, 386, 115-132. [CrossRef]

35. Wimpenny, J.; Manz, W.; Szewzyk, U. Heterogeneity in biofilms. FEMS Microbiol. Rev. 2000, 24, 661-671. [CrossRef]

36. Corrêa Pinto, A.M.; Palomar, T.; Alves, L.C.; da Silva, S.H.M.; Monteiro, R.C.; Macedo, M.F.; Vilarigues, M.G. Fungal biodeterioration of stained-glass windows in monuments from Belém do Pará (Brazil). Int. Biodeterior. Biodegr. 2019, 138, 106-113. [CrossRef]

37. Schabereiter-Gurtner, C.; Pinar, G.; Lubitz, W.; Rölleke, S. Analysis of fungal communities on historical church window glass by denaturing gradient gel electrophoresis and phylogenetic 18S rDNA sequence analysis. J. Microbiol. Methods 2001, 47, 345-354. [CrossRef]

38. Crous, P.; Shivas, R.; Wingfield, M.; Summerell, B.; Rossman, A.; Alves, J.; Adams, G.; Barreto, R.; Bell, A.; Coutinho, M.; et al. Fungal Planet description sheets: 128-153. Pers.-Mol. Phylogeny Evol. Fungi 2012, 29, 146-201. [CrossRef] [PubMed]

39. Corrêa Pinto, A.M. Study and Conservation on Stained-Glass Windows of Historical Buildings from Belém do Pará, Brazil. Ph.D. Thesis, Universidade NOVA de Lisboa, Lisboa, Portugal, 2018.

40. Grinn-Gofron, A. Airborne Aspergillus and Penicillium in the atmosphere of Szczecin, (Poland) (2004-2009). Aerobiologia (Bologna) 2011, 27, 67-76. [CrossRef] [PubMed]

41. Gorbushina, A.A.; Palinska, K.A. Biodeteriorative processes on glass: Experimental proof of the role of fungi and cyano-bacteria. Aerobiologia 1999, 15, 183-191. [CrossRef]

42. Macedo, M.F.; Miller, A.Z.; Dionísio, A.; Saiz-Jimenez, C. Biodiversity of cyanobacteria and green algae on monuments in the Mediterranean Basin: An overview. Microbiology 2009, 155, 3476-3490. [CrossRef]

43. Keshari, N.; Adhikary, S.P. Diversity of cyanobacteria on stone monuments and building facades of India and their phylogenetic analysis. Int. Biodeterior. Biodegrad. 2014, 90, 45-51. [CrossRef]

44. Otlewska, A.; Adamiak, J.; Gutarowska, B. Application of molecular techniques for the assessment of microorganism di-versity on cultural heritage objects. Acta Biochim. Pol. 2014, 61, 217-225. [CrossRef]

45. Diaz-Herraiz, M.; Jurado, V.; Cuezva, S.; Laiz, L.; Pallecchi, P.; Tiano, P.; Sanchez-Moral, S.; Saiz-Jimenez, C. Deterioration of an Etruscan tomb by bacteria from the order Rhizobiales. Sci. Rep. 2015, 4, 3610. [CrossRef]

46. Rosado, T.; Mirão, J.; Candeias, A.; Caldeira, A.T. Characterizing Microbial Diversity and Damage in Mural Paintings. Microsc. Microanal. 2015, 21, 78-83. [CrossRef] 
47. Drewello, U.; Weißmann, R.; Rölleke, S.; Müller, E.; Wuertz, S.; Fekrsanati, F.; Troll, C.; Drewello, R. Biogenic surface layers on historical window glass and the effect of excimer laser cleaning. J. Cult. Herit. 2000, 1, S161-S171. [CrossRef]

48. Heaton, N. Lichens and their Action on the Glass and Leadings of Church Windows. Nat. Cell Biol. 1923, 112, 505-506. [CrossRef]

49. Watanabe, K.; Ohfuji, H.; Ando, J.; Kitagawa, R. Elemental behaviour during the process of corrosion of sekishu glazed roof-tiles affected by Lecidea s.lat. sp. (crustose lichen). Clay Miner. 2006, 41, 819-826. [CrossRef]

50. Watanabe, K.; Ohfuji, H.; Kitagawa, R.; Matsui, Y. Nanoscale pseudobrookite layer in the surface glaze of a Japanese sekishu roof tile. Clay Miner. 2009, 44, 177-180. [CrossRef]

51. Orial, G.; Warscheid, T.; Bousta, F.; Loisel, C. Incidence bactérienne dans les phénomènes de brunissement des vitraux anciens. Actual. Chim. 2007, 312, 34-39.

52. Silva, T.P.; Figueiredo, M.O.; Barreiros, M.A.; Prudêncio, M.I. Diagnosis of pathologies in ancient (seventeenth-eighteenth centuries) decorative blue-and-white ceramic tiles: Green stains in the glazes of a panel depicting Lisbon prior to the 1755 earthquake. Stud. Conserv. 2014, 59, 63-68. [CrossRef]

53. Jongmans, A.G.; Van Breemen, N.; Lundström, U.; Van Hees, P.A.W.; Finlay, R.; Srinivasan, M.; Unestam, T.; Giesler, R.; Melkerud, P.-A.; Olsson, M. Rock-eating fungi. Nat. Cell Biol. 1997, 389, 682-683. [CrossRef]

54. Rana, G.; Mandal, T.; Mandal, N.K.; Sakha, D.; Meikap, B.C. Calcite Solubilization by Bacteria: A Novel Method of Environment Pollution Control. Geomicrobiol. J. 2015, 32, 846-852. [CrossRef]

55. López-Arce, P.; Garcia-Guinea, J.; Fierro, J. Manganese micro-nodules on ancient brick walls. Sci. Total Environ. 2002, 302, 267-274. [CrossRef]

56. Wang, Q.; Ma, G.-Y.; He, L.-Y.; Sheng, X.-F. Characterization of bacterial community inhabiting the surfaces of weathered bricks of Nanjing Ming city walls. Sci. Total Environ. 2011, 409, 756-762. [CrossRef]

57. Gentaz, L.; Lombardo, T.; Chabas, A.; Loisel, C.; Verney-Carron, A. Impact of neocrystallisations on the $\mathrm{SiO}_{2}-\mathrm{K}_{2} \mathrm{O}-\mathrm{CaO}$ glass degradation due to atmospheric dry depositions. Atmos. Environ. 2012, 55, 459-466. [CrossRef]

58. Munier, I.; Lefèvre, R.; Losno, R. Atmospheric factors influencing the formation of neocrystallisations on low durability glass exposed to urban atmosphere. Int. Congr. Glas. 2002, 43C, 114-124.

59. Garcia-Vallès, M.; Vendrell-Saz, M. The glasses of the transept's rosette of the cathedral of Tarragona: Characterisation, classification and decay. Bol. la Soc. Esp. Ceram. y Vidr. 2002, 41, 217-224. [CrossRef]

60. Çalişkan, M. The Metabolism of Oxalic Acid. Turk. J. Zool. 2000, 24, 103-106.

61. Gallien, J.P.; Gouget, B.; Carrot, F.; Orial, G.; Brunet, A. Alteration of glasses by micro-organisms. Nucl. Instrum. Methods Phys. Res. Sect. B Beam Interact. Mater. Atoms 2001, 181, 610-615. [CrossRef]

62. Miller, A.; Dionísio, A.; Braga, M.S.; Hernández-Mariné, M.; Afonso, M.; Muralha, V.; Herrera, L.; Raabe, J.; Fernandez-Cortes, A.; Cuezva, S.; et al. Biogenic Mn oxide minerals coating in a subsurface granite environment. Chem. Geol. 2012, 322-323, 181-191. [CrossRef]

63. Gadd, G.M. Metals, minerals and microbes: Geomicrobiology and bioremediation. Microbiology 2010, 156, 609-643. [CrossRef]

64. Gadd, G.M.; Rhee, Y.J.; Stephenson, K.; Wei, Z. Geomycology: Metals, actinides and biominerals. Environ. Microbiol. Rep. 2012, 4, 270-296. [CrossRef]

65. Vilarigues, M.; da Silva, R. The effect of Mn, Fe and Cu ions on potash-glass corrosion. J. Non-Cryst. Solids 2009, 355, 1630-1637. [CrossRef]

66. Sterpenich, J.; Libourel, G. Using stained glass windows to understand the durability of toxic waste matrices. Chem. Geol. 2001, 174, 181-193. [CrossRef]

67. Guillitte, O. Bioreceptivity: A new concept for building ecology studies. Sci. Total Environ. 1995, 167, 215-220. [CrossRef]

68. Ferrándiz-Mas, V.; Bond, T.; Zhang, Z.; Melchiorri, J.; Cheeseman, C. Optimising the bioreceptivity of porous glass tiles based on colonization by the alga Chlorella vulgaris. Sci. Total Environ. 2016, 563-564, 71-80. [CrossRef]

69. Littmann, E.; Autefage, H.; Solanki, A.; Kallepitis, C.; Jones, J.; Alini, M.; Peroglio, M.; Stevens, M. Cobalt-containing bioactive glasses reduce human mesenchymal stem cell chondrogenic differentiation despite HIF-1 $\alpha$ stabilisation. J. Eur. Ceram. Soc. 2018, 38, 877-886. [CrossRef]

70. Raja, F.N.S.; Worthington, T.; Isaacs, M.A.; Chungong, L.F.; Burke, B.; Addison, O.; Martin, R.A.; Burke, B. The Antimicrobial Efficacy of Hypoxia Mimicking Cobalt Oxide Doped Phosphate-Based Glasses against Clinically Relevant Gram Positive, Gram Negative Bacteria and a Fungal Strain. ACS Biomater. Sci. Eng. 2018, 5, 283-293. [CrossRef]

71. Römich, H.; Jägers, E.; Torge, M.; Müller, W.; Adam, K. Cleaning: A Balancing Act. Available online: https://www.cvma.ac.uk/ conserv / cleaning.html (accessed on 8 October 2021).

72. Coutinho, M.L.; Veiga, J.P.; Macedo, M.F.; Miller, A.Z. Testing the Feasibility of Titanium Dioxide Sol-Gel Coatings on Portuguese Glazed Tiles to Prevent Biological Colonization. Coatings 2020, 10, 1169. [CrossRef]

73. Aversa, R.; Perrotta, V.; Petrescu, R.V.; Carlo, M.; Petrescu, F.I.; Apicella, A. From Structural Colors to Su-per-Hydrophobicity and Achromatic Transparent Protective Coatings: Ion Plating Plasma Assisted $\mathrm{TiO}_{2}$ and $\mathrm{SiO}_{2}$ Nano-Film Deposition. Am. J. Eng. Appl. Sci. 2016, 9, 1037-1045. [CrossRef]

74. Bertoncello, R.; Milanese, L.; Dran, J.C.; Bouquillon, A.; Sada, C. Sol-gel deposition of silica films on silicate glasses: Influence of the presence of lead in the glass or in precursor solutions. J. Non-Cryst. Solids 2006, 352, 315-321. [CrossRef]

75. Bianco, B.D.; Bertoncello, R. Sol-gel silica coatings for the protection of cultural heritage glass. Nucl. Instrum. Methods Phys. Res. Sect. B Beam Interact. Mater. Atoms 2008, 266, 2358-2362. [CrossRef] 